\title{
KARAKTERISASI KOPI BUBUK ROBUSTA (Coffea canephora) TULUNGREJO TERFERMENTASI DENGAN RAGI Saccharomyces cerevisiae
}

\section{CHARACTERIZATION OF ROBUSTA COFFEE (Coffea canephora) FROM TULUNGREJO FERMENTED WITH Saccharomyces cerevisiae}

\author{
Dionesius Budi $^{1}$, Wahyu Mushollaeni*1, Yusianto ${ }^{2}$, Atina Rahmawati ${ }^{1}$ \\ ${ }^{1}$ Program Studi Teknologi Industri Pertanian, Fakultas Pertanian \\ Universitas Tribhuwana Tunggadewi, \\ Jl. Telaga Warna, Tlogomas, Malang, Jawa Timur \\ ${ }^{2}$ Pusat Penelitian Kopi dan Kakao Indonesia \\ Jl. P.B. Sudirman No.90 Jember \\ "Email korespondensi: wahyu.mushollaeni@gmail.com
}

Diterima 17-09-2020, diperbaiki 04-10-2020, disetujui 10-10-2020

\begin{abstract}
Robusta coffee (Coffea canephora) is one type of coffee that is cultivated by the people of Tulungrejo Village, Malang Regency. Until now, the coffee is still sold fresh or dry, because this coffee has a bitter taste and is quite acid so that if it is made into a grounded coffee and consuming it with a high enough frequency it will cause an increase in stomach acid. The presence of caffeine, as well as several types of secondary metabolites, caused the bitter and sour taste in Robusta coffee. Therefore, need a process that is easy, inexpensive, and can be directly applied by the community to reduce levels of caffeine and acid. Fermentation using Saccharomyces cerevisiae yeast is one of the stages of the processing of agricultural products that are most often carried out by the community. However, the effect of fermentation of Robusta coffee from Tulungrejo using S. cerevisiae has never been studied to reduce its acid content. Therefore, this study aimed to obtain the best yeast concentration and fermentation time in making Robusta ground coffee from Tulungrejo so that the acid content was in line with ground coffee standards. The best treatment was obtained by adding $2 \%$ yeast with 10 hours of fermentation time. This treatment produces ground coffee which has a $\mathrm{pH}$ of 5.275; water content $1.75 \%$; ash content $4.81 \%$; and caffeine content of $5.6055 \mathrm{mg} / \mathrm{ml}$. The levels of caffeine and pH had met SNI 1-3542-2004 standards.
\end{abstract}

Keywords: Acid content, caffeine, fermentation, Robusta coffee, Saccharomyces cerevisiae

\begin{abstract}
ABSTRAK
Kopi Robusta (Coffea canephora) merupakan salah satu jenis kopi yang dibudidayakan oleh masyarakat Desa Tulungrejo Kabupaten Malang. Hingga saat ini, hasil kopinya masih dijual dalam bentuk segar atau kering. Hal tersebut disebabkan karena kopi Robusta tersebut mempunyai rasa yang pahit dan cukup asam, sehingga jika dijadikan kopi bubuk dan mengkonsumsinya dengan frekuensi yang cukup tinggi akan mengakibatkan kenaikan asam lambung bagi konsumen. Rasa pahit dan asam tersebut disebabkan adanya kafein, serta beberapa jenis senyawa metabolit sekunder penyebab rasa pahit dan asam dalam kopi Robusta. Oleh karena itu, diperlukan proses yang mudah, murah, dan dapat langsung diaplikasikan oleh masyarakat dengan tujuan untuk mengurangi kadar kafein dan asam. Fermentasi menggunakan ragi Saccharomyces cerevisiae merupakan salah satu tahapan proses
\end{abstract}


pengolahan produk hasil pertanian yang paling sering dilakukan oleh masyarakat. Namun, belum pernah diteliti pengaruh fermentasi kopi Robusta asal Tulungrejo menggunakan S. cerevisiae untuk mengurangi kandungan asamnya. Oleh karena itu, penelitian ini bertujuan untuk mendapatkan konsentrasi ragi dan lama fermentasi terbaik pada pembuatan kopi bubuk Robusta asal Tulungrejo sehingga kadar asamnya sesuai dengan standar kopi bubuk. Perlakuan terbaik diperoleh dengan perlakuan penambahan ragi sebanyak $2 \%$ dengan lama fermentasi 10 jam. Perlakuan ini menghasilkan kopi bubuk yang mempunyai pH 5,28; kadar air 1,75\%; kadar abu 4,81\%; dan kadar kafein 5,6055 $\mathrm{mg} / \mathrm{ml}$. Kadar kafein dan $\mathrm{pH}$ ini telah memenuhi standar SNI 1-3542-2004.

Kata Kunci: Fermentasi, kadar asam, kafein, kopi Robusta, Saccharomyces cerevisiae

\section{PENDAHULUAN}

Indonesia merupakan negara produsen kopi keempat terbesar dunia setelah Brazil, karena hasil perkebunan kopinya cukup melimpah dan memiliki prospek yang bagus untuk dikembangkan. Prospek pengembangan industri kopi di Indonesia meliputi tumbuh kembangnya industri hilir sampai hulu pengolah kopi, sehingga dampaknya akan terciptanya lapangan kerja bagi masyarakat luas, meningkatnya pendapatan petani rakyat, serta dihasilkannya berbagai produk olahan aneka kopi untuk memenuhi kebutuhan masyarakat di Indonesia atau diekspor ke pasar global (Haryanto, 2012).

Kopi Robusta (Coffea canefora) adalah salah satu jenis kopi yang banyak dibudidayakan di Indonesia dan menjadi salah satu komoditas unggulan. Tanaman kopi Robusta pada beberapa penelitian menunjukkan yang cukup tahan terhadap serangan penyakit, serta mempunyai karakteristik rasa yang lebih pahit, sedikit asam dan mengandung kadar kadar kafein lebih tinggi daripada kopi Arabika (Hakim dan Septian, 2011). Desa Tulungrejo Kabupaten Malang adalah salah satu desa yang masyarakatnya membudidayakan tanaman kopi jenis Robusta. Namun hingga saat ini, hasil kopinya masih dijual dalam bentuk segar atau kering. Hal tersebut disebabkan oleh kopi Robusta tersebut mempunyai rasa yang pahit dan cukup asam, sehingga jika meminumnya cukup banyak akan mengakibatkan peningkatan asam lambung bagi konsumen. Rasa pahit dan asam tersebut disebabkan adanya kafein, serta beberapa jenis senyawa metabolit penyebab rasa pahit dan asam dalam kopi Robusta. Clauson et al. (2003) menyatakan bahwa jika terlalu banyak mengkonsumsi kafein dalam kopi, akan mengakibatkan beberapa kondisi yang mempengaruhi metabolisme tubuh diantaranya asidosis, hyperglikemia, dan ketosis.

Senyawa kafein $\left(\mathrm{C}_{8} \mathrm{H}_{10} \mathrm{~N}_{4} \mathrm{O}_{2}\right)$ adalah bagian dari senyawa alkaloid yang mempunyai nama kimia 1,3,7trimethylxanthine (1,3,7-trimethyl-1Hpurine-2, $6(3 \mathrm{H}, \quad 7 H)$-dione $)$. Senyawa kafein tersebut yang salah satunya didapatkan dari konsumsi minuman kopi bubuk adalah senyawa yang dapat berfungsi untuk meningkatkan performa fisik, daya konsentrasi dan memori. Namun demikian, dosis terlalu tinggi dari kafein akan mengakibatkan intoksikasi kafein, pengaruh antagonisme lainnya, dan berbahaya bagi kesehatan. Cukup tingginya jenis dan konsentrasi berbagai asam dalam kopi juga dapat berpengaruh pada kesehatan konsumen kopi bubuk. Diantara senyawa penyebab rasa asam pada kopi bubuk yaitu asam klorogenat dan asamasam organik lainnya (Farhaty dan Muchtaridi, 2014; Nuhu, 2014; Cappelletti et al., 2015; McLellan et al, 2016). Selain itu, konsumsi kopi dengan kadar kafein yang berlebihan hingga mencapai 500-600 mg untuk 5-6 cangkir kopi, dapat menyebabkan otot bergetar, gangguan pencernaan, detak jantung cepat, gugup, dan insomnia. Oleh karena itu, diperlukan proses yang mudah, murah, dan bertujuan untuk mengurangi kadar kafein dan asam 
dalam kopi bubuk terutama yang dihasilkan dari jenis kopi Robusta asal Desa Tulungrejo.

Fermentasi merupakan salah satu tahapan proses pengolahan produk hasil pertanian yang paling mudah dilakukan oleh masyarakat dan lebih murah dibandingkan dengan proses kimia dan fisik lainnya yang menggunakan peralatan modern. Proses fermentasi dilakukan untuk menurunkan komponen-komponen dalam suatu biji tanaman diantaranya asam sianida, klorogenat, serta beberapa jenis asam organik yang dapat berakibat negatif apabila dikonsumsi dalam jumlah berlebih oleh konsumen. Fermentasi tersebut melibatkan peran mikroorganisme, diantaranya ragi, kapang, dan bakteri (Triyono dkk., 2019; Mushollaeni et al., 2019; Wijayanti dkk., 2019).

Usaha peningkatan produksi kopi rendah asam dan kafein saat ini masih terus dikembangkan, karena beberapa penelitian yang telah ada masih sulit untuk diterapkan petani kopi terutama dengan penggunaan berbagai bahan kimia dan peralatan yang tidak dimiliki oleh petani. Oleh karena itu, dalam penelitian ini bertujuan untuk mendapatkan konsentrasi ragi dan lama fermentasi terbaik pada pembuatan kopi bubuk Robusta asal Tulungrejo sehingga kadar asamnya sesuai dengan standar kopi bubuk.

\section{BAHAN DAN METODE}

\section{Alat dan Bahan}

Peralatan yang digunakan pada penelitian ini adalah mesin penyangrai biji kopi (probat), panci, penggering kopi (dry house), timbangan analitik, peralatan gelas laboratorium, oven listrik, stopwatch, penapis, gunting, sensor suhu, desikator, alumunium foil, tanur, krus porselin, botol sampel 10 gram, platform shaker, kolom gelas, spectrometer uv-vis (+kuvet quart $1 \mathrm{~cm}$ palth). Bahan-bahan yang digunakan adalah biji kopi Tulungrejo yang telah disortir, dikupas, difermentasi, dicuci dan dikeringkan selama 1 minggu, aquades, dan
$\mathrm{pH}$ meter, celite 545 (pa), chloroform, ether, $2 \mathrm{~N} \mathrm{NaOH}, \mathrm{NH}_{4} \mathrm{OH}(1+2), 4 \mathrm{~N}$ (setara dengan $2 \mathrm{M}$ ) $\mathrm{H}_{2} \mathrm{SO}_{4}$, ether yang dijenuhkan dengan $\mathrm{H}_{2} \mathrm{O}$, dan chloroform yang dijenuhkan dengan $\mathrm{H}_{2} \mathrm{O}$.

\section{Metode}

Proses pembuatan bubuk kopi ini didasarkan dari penelitian yang telah dilakukan sebelumnya dengan menggunakan kopi Liberika (Triyono dkk., 2019 dan Wijayanti dkk., 2019). Biji kopi yang telah disortasi, kemudian ditimbang, dan dicuci hinga bersih, kemudian difermentasi menggunakan ragi dengan perbandingan $1,5 \% ; 2,5 \%$; dan $3,5 \%$ dengan waktu fermentasi yaitu 4 jam, 8 jam, dan 12 jam. Kopi hasil fermentasi kemudian dicuci dan dikeringkan selama 3 jam dengan suhu $50^{\circ} \mathrm{C}$, kemudian disangrai selama 25 menit. Kopi diblender dan diayak dengan menggunakan ayakan 60 mesh untuk menghasilkan kopi bentuk bubuk.

Rancangan Acak Kelompok Pola Faktorial yang terdiri atas dua faktor yaitu konsentrasi ragi (R) dan lama fermentasi (F) digunakan dalam penelitian. Karakteristik kopi bubuk dianalisis dengan parameter nilai $\mathrm{pH}$ menggunakan metode PUSLITKOKA Jember (Pusat Penelitian Kopi dan Kakao Indonesia), serta kadar air dan kadar abu menggunakan metode AOAC (2000). Analisis pH menggunakan prinsip titrasi asam basa. Kadar kafein menggunakan metode PUSLITKOKA Jember, yang dilakukan pada perlakuan yang terbaik. Pengujian kadar kafein dilakukan dengan tiga tahap. Tahap pertama adalah melakukan isolasi kandungan kafein kopi bubuk murni, kopi mentah, dan kopi bubuk campuran, kemudian dilanjutkan pada tahap kedua adalah pembuatan larutan baku kafein. Tahap ketiga adalah pembuatan kurva standar dan larutan standar. Larutan standar kafein diukur dengan spektrofotometer UVVis sehingga diperoleh $\lambda$ max. Ekstrak kafein dari masing-masing sampel kopi yang bebas pelarut dimasukkan ke dalam 
labu ukur $100 \mathrm{~mL}$ dan dilakukan pengeceran 10 kali pada labu ukur $10 \mathrm{~mL}$ dengan aquades hingga tanda tera, kemudian dihomogenkan. Penentuan kadarnya menggunakan spektrofotometri UV-Vis pada panjang gelombang $275 \mathrm{~nm}$. Perlakuan yang sama dilakukan untuk tiaptiap sampel bubuk kopi dengan berat 1 gram. Pengujian organoleptik menggunakan metode PUSLITKOKA Jember oleh panelis ahli kopi.

Panelis melakukan organoleptik dengan cara melihat, mencium, dan menyeduh kopi bubuk. Uji organoleptik ini dilakukan pada semua sampel dengan menguji aroma, rasa, dan tekstur, menggunakan parameter dan skor terhadap fragrance (aroma), flavor (rasa), aftertaste (sisa rasa), acidity (keasaman), body (fisik), uniformity (keseragaman), balance (keseimbangan), clean cup (kebersihan), sweetness (rasa manis), dan overall (keseluruhan). Analisa data menggunakan ANOVA untuk RAK pola faktorial dan perlakuan terbaik menggunakan metode DeGarmo et al. (1984) dan Susrini (2003).

\section{HASIL DAN PEMBAHASAN}

\section{Nilai pH}

$\mathrm{pH}$ atau derajat keasaman merupakan salah satu indikator kopi bubuk dari hasil fermentasi. Standar keasaman kopi menurut Ridwansyah (2003) adalah tidak boleh lebih rendah dari 4. Berbagai jenis asam yang merupakan produk metabolit sekunder terdapat dalam biji kopi dan terikat kuat dalam sel, diantaranya jenis asam karboksilat yaitu asam format, asam asetat, asam oksalat, asam sitrat, asam laktat, asam malat, dan asam quinat. Dalam jumlah yang tepat, jenis asam tersebt akan membentuk cita rasa khas kopi, terutama terbentuk saat penyangraian kopi. Terbukanya ikatan pengikat senyawa metabolit diantaranya ikatan glikosida, mengakibatkan lepasnya asam tersebut menjadi bentuk bebas (Widyotomo dkk., 2009). $\begin{array}{crr}\text { Fermentasi } & \text { juga mampu } \\ \text { menguraikan ikatan glikosida yang }\end{array}$ mengikat senyawa bioaktif dan metabolit sekunder yang berada dalam sel biji tanaman (Mushollaeni et al., 2018; Mushollaeni and Tantalu, 2019), sehingga menjadi aglikon bebas. Hasil penelitian menunjukkan bahwa semakin lama waktu fermentasi, secara umum akan menurunkan nilai $\mathrm{pH}$ atau tingkat keasaman menjadi lebih tinggi, namun tingkat penurunannya terkait dengan perlakuan konsentrasi ragi yang digunakan. Berdasarkan hasil penelitian, $\mathrm{pH}$ tertinggi didapatkan pada perlakuan konsentrasi ragi 1,5\% dengan waktu 10 jam yaitu 5,37, sedangkan $\mathrm{pH}$ terendah diperoleh pada perlakuan konsentrasi ragi 2,5\% dengan waktu 8 jam yaitu 5,25 . Seluruh perlakuan memberikan nilai $\mathrm{pH}$ di atas 5 yang berarti telah memenuhi standar yaitu lebih dari 4 (Gambar 1). Apabila fermentasi ini dilanjutkan hingga lebih dari 12 jam yaitu hingga 14 jam, terjadi penurunan kadar $\mathrm{pH}$ hingga mendekati $4(\mathrm{pH} \mathrm{4,3)}$ dan terus berlanjut menurun hingga 3,8 .

Perhitungan ANOVA menyatakan bahwa faktor perbedaan konsentrasi ragi dan lama fermentasi berpengaruh tidak nyata terhadap nilai keasaman kopi bubuk. Perbedaan nyata ditunjukkan oleh perbedaan tiap kelompok perlakuan. Hal tersebut menunjukkan bahwa pemberian konsentrasi ragi hingga 2,5\% (b/b) dengan lama fermentasi hingga 12 jam telah cukup atau dapat menupakan batasan maksimal yang dapat memberikan hasil kadar $\mathrm{pH}$ yang baik dan sesuai dengan standar SNI.

Penurunan nilai $\mathrm{pH}$ tersebut sejalan dengan penelitian yang dilakukan oleh Obadina et al. (2013), serta Oluwabamiwa and Kolapo (2007) yang menyatakan bahwa selama fermentasi terjadi pertumbuhan mikroba dan terbentuk jenisjenis asam sebagai hasil metabolisme diantaranya asam laktat, sehingga mengakibatkan penurunan nilai $\mathrm{pH}$ dari rata-rata $\mathrm{pH}$ normal 7 menjadi rata-rata berada ada pada kisaran $\mathrm{pH} 4$. 


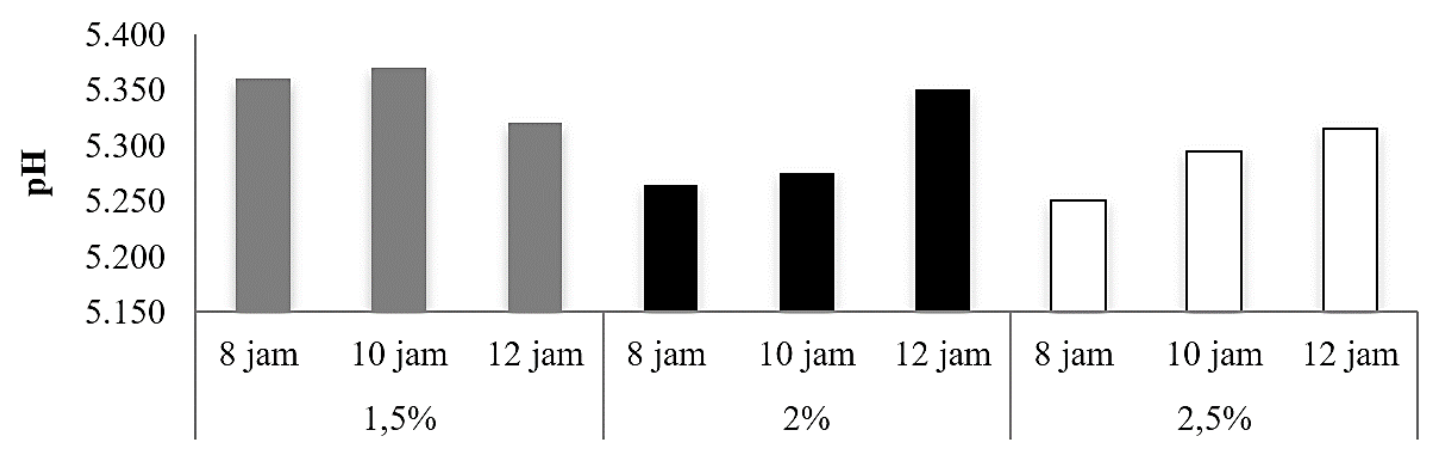

Perlakuan konsentrasi ragi (\%) dan lama fermentasi (jam)

Gambar 1. pH kopi bubuk

Kadar Air (\%)

Salah satu syarat mutu kopi bubuk berdasarkan SNI kopi bubuk (SNI 01-35422004) adalah mempunyai kadar air maksimal $7 \%$ (b/b). Hasil penelitian menunjukkan bahwa kadar air kopi bubuk Robusta Tulungrejo yang difermentasi dengan ragi telah sesuai dengan standar tersebut yaitu berkisar antara 1,17-3,62\% (b/b). Hasil analisa ANOVA menunjukkan bahwa kadar air kopi bubuk memberikan pengaruh yang tidak nyata antar perlakuan. Adanya peningkatan kadar air selama fermentasi tampak pada jam ke-10 fermentasi Gambar 2. Hal tersebut dimungkinkan terjadi karena proses penggunaan air oleh mikroba masih belum maksimal. Proses respirasi mikroba yang juga menghasilkan air masih belum banyak digunakan kembali dalam proses metabolisme berikutnya.

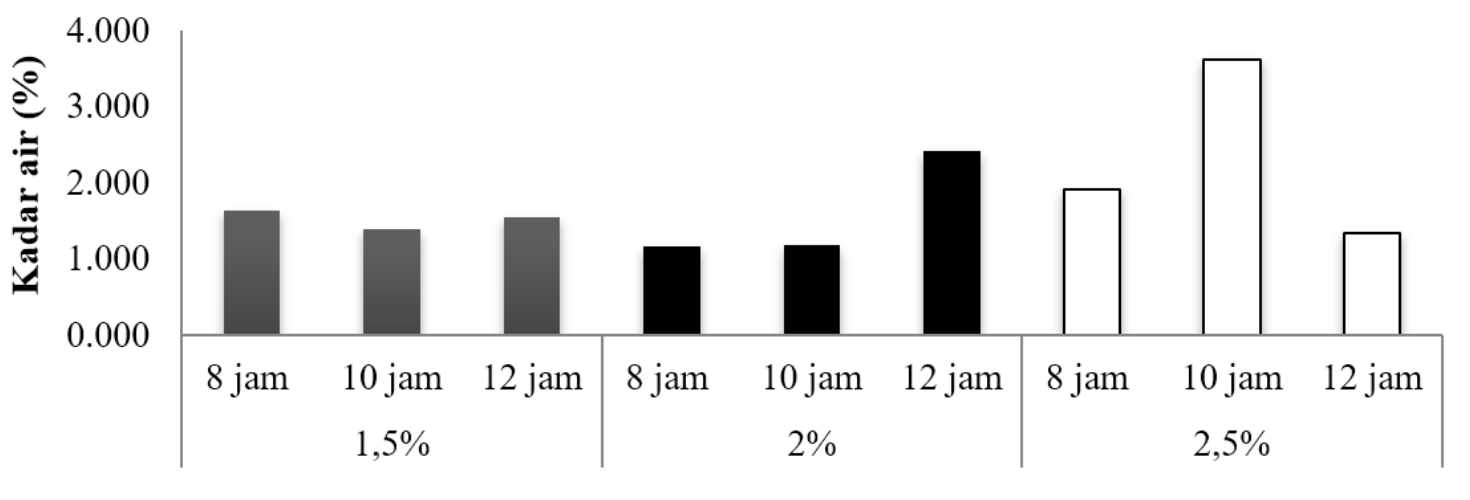

Perlakuan konsentrasi ragi (\%) dan lama fermentasi (jam)

Gambar 2. Kadar air kopi bubuk

Selama fermentasi, mikroba termasuk ragi melakukan proses metabolisme untuk mendapatkan senyawa-senyawa yang dibutuhkan untuk mendukung pertumbuhannya. Dalam mendukung proses metabolisme tersebut, keterlibatan air sangat penting dalam proses pengubahan komponen dalam sel menjadi energi dan berbagai kegiatan pemecahan senyawa komplek menjadi senyawa sederhana yang dibutuhkannya. Oleh karenanya, terjadi penurunan yang nyata untuk kadar air dan menurut Morris et al. (2004) kadar air ini akan menurun tajam hingga 72 jam fermentasi.

\section{Kadar Abu (\%)}

Kadar abu kopi bubuk pada semua perlakuan menunjukkan kisaran antara 4,6 hingga 4,9\% (b/b). Kadar abu tersebut telah 
sesuai dengan standar SNI kopi bubuk yang menyatakan kadar abu kopi bubuk tidak lebih dari $5 \%(\mathrm{~b} / \mathrm{b})$. Kadar abu terendah $(4,64 \% \mathrm{~b} / \mathrm{b})$ dicapai dari perlakuan penggunaan ragi sebanyak $2,5 \%$ dan 10 hari lama fermentasi, sedangkan kadar abu tertinggi $(4,93 \% \mathrm{~b} / \mathrm{b})$ pada penambahan ragi sebanyak $2 \%$ dengan 8 hari fermentasi. Jika dibandingkan dengan kadar abu dari kopi lokal jenis Arabika dan Robusta yang diteliti oleh Pigozii et al. (2018) adalah berkisar 4,48-9,44\% (b/b), maka kadar abu kopi bubuk Robusta Tulungrejo masih lebih rendah.

Kadar abu yang terdapat dalam kopi bubuk merupakan mineral dan bahan organik yang tersisa dari hasil pengabuan. Hal ini sejalan dengan yang dinyatakan oleh Tarigan dan Towaha (2017) bahwa abu dalam kopi adalah bahan anorganik yang tertinggal dari proses pengabuan. Selain itu, kadar abu yang terdapat dalam biji tanaman termasuk biji kopi dipengaruhi oleh tingkat kesuburan tanah tempat tumbuh tanaman, komposisi mineral dalam tanah, dan lokasi tempat tumbuhnya. Namun apabila kadar abu kopi lebih dari $5 \%(\mathrm{~b} / \mathrm{b})$, maka diindikasikan adanya kandungan bahan asing (impurities) (Muller et al., 2013; Oliveira et al., 2013). Kadar abu kopi bubuk Robusta hasil fermentasi dengan ragi, dapat dilihat pada Gambar 3. Berdasarkan Gambar 3, perbedaan antar perlakuan tidak nyata dan hal ini juga menunjukkan bahwa kadar abu dalam biji kopi Robusta asal Tulungrejo tidak banyak terpengaruh oleh proses fermentasi.

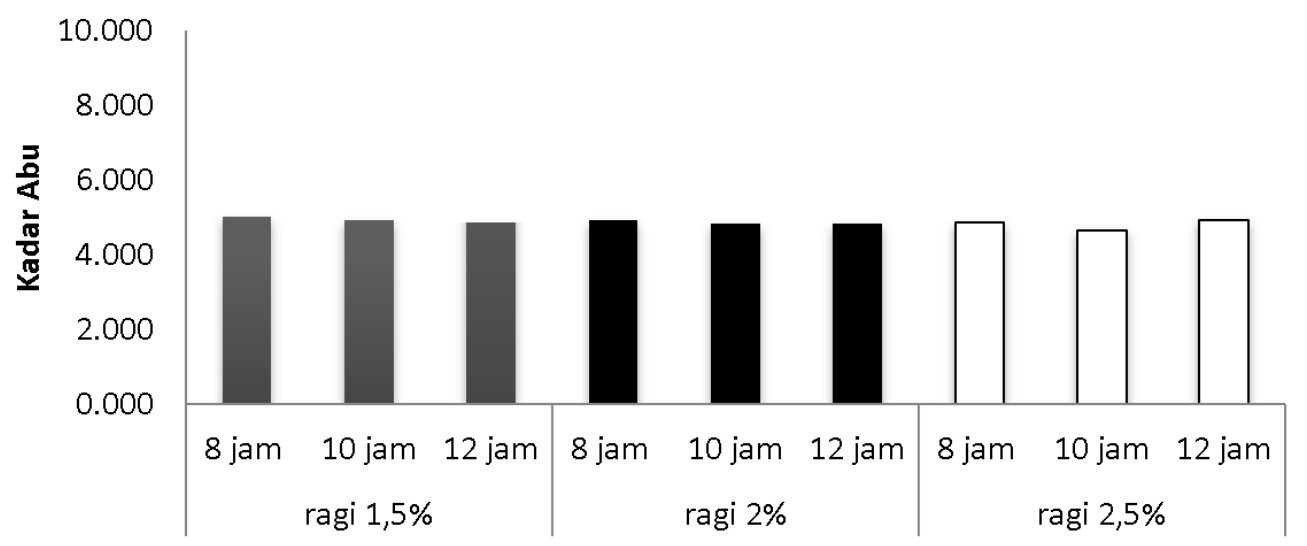

Perlakuan konsentrasi ragi (\%) dan lama fermentasi (jam)

Gambar 3. Kadar abu kopi bubuk

\section{Kadar Kafein}

Biji kopi secara alami mengandung kafein dalam kadar yang beragam sesuai dengan persyaratan dan tempat tumbuh tanaman, karena kafein merupakan bagian dari metabolit sekunder yang dihasilkan oleh tanaman sebagai bentuk perlindungan diri terhadap lingkungan dan kompetitor. Kandungan bahan alami atau fitonutrisi dalam tanah tempat tumbuh tanaman, tingkat kematangan biji, kesuburan tanah, dan kondisi genetik tanaman berpengaruh terhadap kandungan kafein (Mulato dan
Suharyanto, 2012; Santos et al., 2016; Panusa et al., 2017; Gaibor et al., 2020).

Kadar kafein yang dipersyaratkan dalam SNI 1-3542-2004 adalah 0,45-2 dan $0,9-2 \%$. Rata-rata kadar kafein dari kopi bubuk yang difermentasi dengan ragi adalah $5,6055 \mathrm{mg} / \mathrm{ml}$ dan $6,1754 \mathrm{mg} / \mathrm{ml}$ atau setara dengan $0,561-0,618 \%$, sehingga telah memenuhi standar SNI. Uji kadar kafein dalam penelitian ini dilakukan untuk perlakuan terbaik yang merupakan perlakuan terbaik berdasarkan nilai $\mathrm{pH}$, kadar air, dan kadar abu. Berdasarkan 
perhitungan perlakuan terbaik tersebut, hasil tertinggi didapatkan pada perlakuan pernggunaan konsentrasi ragi sebanyak $2 \%$ dengan 10 jam lama fermentasi (Tabel 1).

Tabel 1. Nilai pH, kadar air, dan kadar abu kopi bubuk Robusta Tulungrejo

\begin{tabular}{lcccc}
\hline \multicolumn{1}{c}{ Perlakuan } & $\mathrm{pH}$ & Kadar air & Kadar abu & Total NH \\
\hline konsentrasi ragi 1,5 \%; waktu 8 jam & 0,370 & 0,290 & 0,289 & 0,949 \\
konsentrasi ragi 2\%; waktu 8 jam & 0,377 & 0,330 & 0,290 & 0,997 \\
konsentrasi ragi 2,5\%; waktu 8 jam & 0,378 & 0,264 & 0,292 & 0,933 \\
konsentrasi ragi 1,5\%; waktu 10 jam & 0,369 & 0,310 & 0,291 & 0,970 \\
konsentrasi ragi 2 \%; waktu 10 jam & 0,376 & 0,330 & 0,293 & $\mathbf{0 , 9 9 8 *}$ \\
konsentrasi ragi 2,5\%; waktu 10 jam & 0,375 & 0,109 & 0,296 & 0,780 \\
konsentrasi ragi 1,5\%; waktu 12 jam & 0,373 & 0,297 & 0,199 & 0,869 \\
konsentrasi ragi 2\%; waktu 12 jam & 0,371 & 0,218 & 0,292 & 0,881 \\
konsentrasi ragi 2,5\%; waktu 12 jam & 0,373 & 0,314 & 0,290 & 0,978
\end{tabular}

Keterangan : * merupakan NH tertinggi dan sebagai perlakuan terbaik

\section{Pengujian Organoleptik}

Pengujian organoleptik dalam penelitian ini merupakan pengujian kesukaan panelis terlatih terhadap kopi bubuk yang dihasilkan dari setiap perlakuan. Panelis terlatih tersebut adalah tiga orang ahli kopi yang berasal dari Pusat Penelitian Kopi Dan Kakao Indonesia (Jember). Pengujian tersebut dilakukan dengan cara melihat, mencium (membau), dan menyeduh kopi bubuk untuk semua kopi bubuk perlakuan. Keseluruhan kopi bubuk diuji dari segi fragrance (aroma), flavor (rasa), aftertaste (sisa rasa), acidity (keasaman), body (fisik), uniformity (keseragaman), balance (keseimbangan), clean cup (kebersihan), sweetness (rasa manis), serta overall (keseluruhan) menggunakan skor yang telah ditetapkan oleh Pusat Penelitian Kopi Dan Kakao Indonesia (Jember) untuk standar mutu kopi (Tabel 2).

Tabel 2. Hasil penilaian organoleptik kopi bubuk

\begin{tabular}{|l|c|c|c|c|c|c|c|c|c|}
\hline \multicolumn{1}{|c|}{ Jenis uji } & R1F1 & R2F1 & R3F1 & R1F2 & R2F2 & R3F2 & R1F3 & R2F3 & R3F3 \\
\hline Fragrance & 7.58 & 7.54 & 7.46 & 7.50 & 8.04 & 7.63 & 7.67 & 7.79 & 7.63 \\
\hline Falvor & 7.52 & 7.54 & 7.50 & 7.71 & 7.96 & 7.54 & 7.71 & 7.63 & 7.75 \\
\hline Aftertaste & 7.42 & 7.54 & 7.38 & 6.42 & 7.83 & 7.46 & 7.71 & 7.71 & 7.79 \\
\hline Acidity & 7.58 & 7.63 & 7.63 & 7.88 & 8.13 & 7.54 & 7.67 & 7.58 & 7.88 \\
\hline Body & 7.63 & 7.58 & 7.58 & 7.75 & 8.04 & 7.42 & 7.79 & 7.80 & 7.67 \\
\hline Uniformity & 10.00 & 10.00 & 10.00 & 10.00 & 10.00 & 10.00 & 10.00 & 10.00 & 10.00 \\
\hline Balance & 7.46 & 7.50 & 7.63 & 7.75 & 7.83 & 7.54 & 7.75 & 7.71 & 7.75 \\
\hline Clean up & 10.00 & 10.00 & 10.00 & 10.00 & 10.00 & 10.00 & 10.00 & 10.00 & 10.00 \\
\hline Sweetness & 7.67 & 7.88 & 7.54 & 7.75 & 7.96 & 7.42 & 7.88 & 7.83 & 7.67 \\
\hline Overall & 7.58 & 7.54 & 7.50 & 7.71 & 7.50 & 7.46 & 7.79 & 7.63 & 7.79 \\
\hline Rerata & 8.04 & 8.08 & 8.02 & 8.05 & $\mathbf{8 . 3 3} *$ & 8.00 & 8.20 & 8.17 & 8.19 \\
\hline
\end{tabular}

Keterangan : angka yang bercetak tebal dengan tanda bintang menunjukkan nilai tertinggi dan merupakan perlakuan terbaik yaitu pada perlakuan R2F2 (penggunaan konsentrasi ragi sebanyak 2\% dengan 10 jam lama fermentasi).

Tabel 2 menunjukkan bahwa perlakuan penggunaan konsentrasi ragi sebanyak $2 \%$ dengan 10 jam lama fermentasi merupakan perlakuan terbaik didasarkan dari pengujian organoleptik oleh para ahli kopi. Hasil pengujian perlakuan terbaik berdasarkan parameter kimia dan organoleptik menunjukkan hasil yang sama, sehingga dapat disimpulkan bahwa kopi Robusta asal Desa Tulungrejo Kabupaten Malang dapat diolah menjadi kopi bubuk menggunakan perlakuan fermentasi selama 10 jam dengan penambahan ragi $\mathrm{S}$. cerevisiae sebanyak $2 \%$, untuk mendapatkan kopi bubuk yang berkualitas. Proses pengolahan tersebut akan menghasilkan kopi bubuk dengan nilai $\mathrm{pH}$, kadar abu, kadar air, dan kadar 
kafein berturut-turut yaitu 5,$28 ; 1,18 \%$; $4,81 \%$; dan $5,6055 \mathrm{mg} / \mathrm{ml}$.

\section{KESIMPULAN}

Berdasarkan hasil kegiatan penelitian, pengolahan kopi Robusta asal Desa Tulungrejo menggunakan metode fermentasi untuk menghasilkan kopi bubuk yang berkualitas, diperoleh dengan perlakuan penambahan ragi sebanyak $2 \%$ dengan lama fermentasi 10 jam. Perlakuan terbaik tersebut dapat memperbaiki nilai pH kopi bubuk yang tidak diperlakukan dengan fermentasi yaitu 3,5 menjadi 5,28 dan mampu menurunkan kadar kafein kopi bubuk yang tidak difermentasi yaitu 1,2$2,5 \%$ menjadi $0,561-0,618 \%$. Perlakuan terbaik tersebut juga menghasilkan kopi bubuk yang mempunyai kadar air 1,75\% dan kadar abu 4,81\%. Keseluruhan parameter tersebut telah memenuhi standar SNI 1-3542-2004.

\section{UCAPAN TERIMAKASIH}

Terimakasih disampaikan kepada Kepala Pusat Penelitian Kopi dan Kakao Indonesia (Jember), Bapak Yusianto dan peneliti kopi di Pusat Penelitian Kopi dan Kakao Indonesia (Jember), Laboratorium Rekayasa Proses dan Laboratorium Mikrobiologi Industri FP UNITRI atas pemberian ijin penelitian, serta penyediaan sarana dan prasarana yang sangat mendukung penelitian.

\section{DAFTAR PUSTAKA}

AOAC International. 2000. Official methods of analysis of AOAC International. 17th ed. Association of Analytical Communities. Gaithersburg.

Cappelletti, S., P. Daria, G. Sani, and M. Aromatario. 2015. Caffeine: cognitive and physical performance enhancer or psychoactive drug? Curr Neuropharmacol, 13(1):71-88.
Clauson, K.A., K.M. Shields, C.E. McQueen and N. Persad. 2008. Safety issues associated with commercially available energy drinks. J. Am. Pharm. Assoc., 48(3): e55-63; quiz e64-7.

DeGarmo, E.P., W.G. Sullivan, and C.R. Canada. 1984. Engineering Economy. $7^{\text {th }}$ Edition. McMillan Publisshing Co., New York.

Tarigan, E.B. dan J. Towaha. 2017. Pengaruh tingkat kematangan buah, serta lama fermentasi dan penyangraian biji terhadap karakter fisikokimia kopi Robusta. J. TIDP, 4(3):163-170.

Farhaty, N. dan Muchtaridi. 2014. Tinjauan kimia dan aspek farmakologi senyawa asam klorogenat pada biji kopi : Review. Farmaka Suplemen, 14(1):214-227.

Gaibor, J., D. Morales and W. Carrillo. 2020. Determination of caffeine content in Robusta roasted coffee (Coffea canephora) by RP-UHPLCPDA. Asian Journal of Crop Science, 12:90-96.

Hakim, L. dan A. Septian. 2011. Prosepek ekspor kopi arabika organik bersertifikat di Kabupaten Aceh Tengah. Jurnal Agrisep, 12(1):1-8.

Haryanto, B. 2012. Prospek Tinggi Bertanam Kopi. Pustaka Baru Press, Yogyakarta.

McLellan, T.M., J.A. Caldwell, and H.R. Lieberman. 2016. A review of caffeine's effects on cognitive, physical and occupational performance. Neuroscience and Biobehavioral Reviews, 71:294312.

Morris, A., A. Barnett and O. Burrows. 2004. Effect of processing on 
nutrient content of foods. Cajarticles, 37:160-164.

Mulato, S. dan E. Suharyanto. 2012. Kopi, seduhan \& kesehatan. Pusat Penelitian Kopi dan Kakao Indonesia.

Muller, A.J., L. Huebner and C.F.V. Souza. 2013. Evaluation of physicochemical quality of diferent brands of roasted cofee soluble and in powder marketed in the region of Vale do Taquari/RS. Revista Brasileira de Tecnologia Agroindustrial, 7:1004-1012.

Mushollaeni, W. and L. Tantalu. 2019. Determination and Characterization of Phenolics, Flavonoids, and Dietary Fiber in Fermented Lebui Bean (Cajanus sp.) Extracts by the SSF Method. Bioscience Research 16(2):1600-1606.

Mushollaeni, W., R. Sanny, R.M. Nyonya and T.M. Maf. 2019. Effect of immersion fermentation on decreasing of cyanide acid and physicochemical content of local Hevea brasiliensis seeds from Borneo Indonesia. Biosci. Res., 16(1):667-671.

Nuhu, A.A 2014. Bioactive micronutrients in coffee: recent analytical approaches for characterization and quantification. ISRN Nutrition, 13 pages.

Obadina, A.O., O.J. Akinola, T.A. Shittu and H.A. Bakare. 2013. Effect of Natural Fermentation on the Chemical and Nutritional Composition of Fermented Soymilk. Nigerian Food Journal, 31(2):91-97.

Oliveira, P.D., F.M Borem, E.P. Isquierdo, G.D.S. Giomo, R.R. de Lima, and R.A. Cardoso. 2013. Physiological aspects of cofee beans, processed and dried through diferent methods, associated with sensory quality. Coffee Science, 8(2):211-220.

Olubamiwa, A.L. and A.O. Kolapo. 2007. Effect of different concentrations of coconut milk on the chemical and sensory properties of soy-coconut milk based yoghurt. Food and Public Health, 2(4):85-91.

Panusa, A., R. Petrucci, R. Lavecchia and A. Zuorro. 2017. UHPLC-PDAESI-TOF/MS metabolic profiling and antioxidant capacity of Arabica and Robusta coffee silverskin: Antioxidants vs phytotoxins. Food Res. Int., 99:155-165.

Pigozzi, M.T., Passos, F.R. and Mendes, F.Q. 2018. Quality of commercial coffees: heavy metal and ash contents. Journal of Food Quality, 1-7.

Ridwansyah. 2003. Pengolahan kopi. Jurusan Teknologi Pertanian. Fakultas Pertanian. Universitas Sumatera Utara. Diakses pada 10 September 2020. http://repository.usu.ac.id/bitstream/ handle/123456789/776/tekper-ridwansyah4.pdf;jsessi onid=CEA23501B04C2BC3AC80CC168D9532D9 ?sequence $=1$

Santos, J.R., Lopo, M., Rangel, A.O.S.S. and Lopes, J.A. 2016. Exploiting near infrared spectroscopy as an analytical tool for on-line monitoring of acidity during coffee roasting. Food Control, 60: 408415.

Susrini. 2003. Index Efektifitas. Suatu Pemikiran tentang Alternatif untuk Memilih Perlakuan Terbaik pada Penelitian Pangan. Edisi Kedua. Program Studi Teknologi Hasil Ternak. Fakultas Peternakan. Universitas Brawijaya. Malang. 
Triyono, Mushollaeni, W. dan Wirawan. 2019. Proses penurunan kadar asam pada kopi varietas liberika dengan cara fermentasi menggunakan enzim papain dan ragi instan. Diakses pada 10 September 2020. https://publikasi.unitri.ac.id/index.p $\mathrm{hp} /$ pertanian/article/view/1425.

Widyotomo, S., Mulato, S., Purwadaria, H.K. dan Syarief, A.M. 2009. Decaffeination process characteristic of Robusta coffee in single column reactor using ethyl acetate solvent. Pelita Perkebunan.
A Coffee and Cocoa Research Journal, 25(2).

Wijayanti, P., Mushollaeni, W. dan Rozana. 2019. Produksi kopi bubuk rendah asam dari kopi liberika (Coffea liberica) dengan metode fermentasi menggunakan ragi (Saccharomyces sp.). Diakses pada $10 \quad$ September 2020. https://publikasi.unitri.ac.id/index.p $\mathrm{hp} /$ pertanian/article/view/1495. 